\title{
PHYTOCHEMICAL AND ANTIOXIDANT COMPOSITION IN ACCESSIONS OF THE MANGABA ACTIVE GERMPLASM BANK ${ }^{1}$
}

\author{
PRISCILLA SANTANA SANTOS ${ }^{2}$, LISIANE DOS SANTOS FREITAS ${ }^{2}$, EVANDRO NEVES MUNIZ ${ }^{3}$, JOSEFA \\ GRASIELA SILVA SANTANA ${ }^{4}$, ANA VERUSKA CRUZ DA SILVA ${ }^{3 *}$
}

\begin{abstract}
Mangaba (Hancornia speciosa Gomes) is a fruit species native to Brazil, belonging to the Apocynaceae family. Its cultivation is predominantly extractivist and its antioxidant properties have been recently reported. The objective of this study was to evaluate the bioactive compounds and antioxidant activity in fruits of accession from the Active Germplasm Bank of Embrapa Coastal Tablelands (BI, CA, LG, PR, PT and TC). The extracts were analyzed by high-performance liquid chromatography (HPLC), which

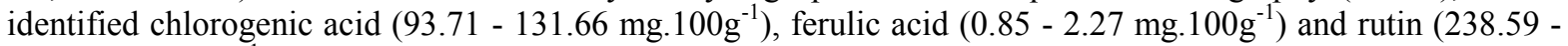
$\left.442.94 \mathrm{mg} .100 \mathrm{~g}^{-1}\right)$. The accessions CA and PR showed the highest values of total phenols (1179.39 and $1167.05 \mathrm{mg} \mathrm{GAE} .100 \mathrm{~g}^{-1}$, respectively). The accessions CA and TC had the highest concentration of the major compound rutin (436.78 and $442.94 \mathrm{mg} .100 \mathrm{~g}^{-1}$, respectively). Antioxidant activity values ranged from 125.95 to $158.67 \mathrm{~g} . \mathrm{g}^{-1} \mathrm{DPPH}$. Principal component analysis grouped the accessions into four groups, due to the genetic variability verified in previous studies. The results will be useful to guide actions of selection and future breeding program of the species.
\end{abstract}

Keywords: Brazilian fruits. Phenolic compounds. Rutin. Antioxidant activity.

\section{COMPOSIÇÃO FITOQUÍMICA E ANTIOXIDANTE EM ACESSOS DO BANCO ATIVO DE GERMOPLASMA DE MANGABA}

RESUMO - A mangabeira (Hancornia speciosa Gomes) é uma espécie frutífera nativa do Brasil, pertencente à família Apocynaceae. Seu cultivo é predominantemente extrativista e suas propriedades antioxidantes têm sido recentemente relatadas. O objetivo do presente trabalho foi avaliar os compostos bioativos e atividade antioxidante em frutos de acessos oriundos do Banco Ativo de Germoplasma da Embrapa Tabuleiros Costeiros (BI, CA, LG, PR, PT e TC). Os extratos foram analisados em cromatografia líquida de alta eficiência (HPLC) e identificou-se o ácido clorogênico $\left(93,71\right.$ - 131,66 mg. $\left.100 \mathrm{~g}^{-1}\right)$; ácido ferúlico $\left(0,85-2,27 \mathrm{mg} \cdot 100 \mathrm{~g}^{-1}\right)$ e rutina (238,59 - 442,94 mg.100g $\left.\mathrm{g}^{-1}\right)$. Os acessos CA e PR apresentaram os maiores valores de fenóis totais (1179,39 e $1167,05 \mathrm{mg}$ EAG.100g ${ }^{-1}$, respectivamente). Os acessos CA e TC apresentaram a maior concentração do composto majoritário rutina $\left(436,78\right.$ e $442,94 \mathrm{mg} .100 \mathrm{~g}^{-1}$, respectivamente). Os valores da atividade antioxidante variaram entre 125,95 e 158,67 g.g ${ }^{-1}$ DPPH. A análise de componentes principais agrupou os acessos em quatro grupos, em consequência da variabilidade genética previamente verificada em estudos anteriores. Os resultados serão úteis para direcionar ações de seleção e futuro programa de melhoramento genético da espécie.

Palavras-chaves: Frutas brasileiras. Compostos fenólicos. Rutina. Atividade antioxidante.

\footnotetext{
${ }^{*}$ Corresponding author

${ }^{1}$ Received for publication in 06/19/2020; accepted in 07/13/2020.

Paper extracted from the doctoral thesis of the first author.

${ }^{2}$ Department of Chemistry, Universidade Federal de Sergipe, São Cristovão, SE, Brazil; priscillita-ss@hotmail.com - ORCID: 0000-00015844-696X, lisiane_santos_freitas@yahoo.com.br - ORCID: 0000-0002-6720-8338.

${ }^{3}$ Embrapa Tabuleiros Costeiros, Aracaju, SE, Brazil; evandro.muniz@embrapa.br - ORCID: 0000-0003-2806-229X, ana.veruska@embrapa.br - ORCID: 0000-0002-4177-9335.

${ }^{4}$ Agricultural Engineering Laboratory, Universidade Estadual do Norte Fluminense, Campos dos Goytacazes, RJ, Brazil; grasi_agronomia@hotmail.com - ORCID: 0000-0002-4257-6652.
} 


\section{INTRODUCTION}

The great biodiversity of Brazilian native fruit species, with nutritional and pharmacological potential, is still little explored. These species include mangaba (Hancornia speciosa Gomes), of the Apocynaceae family, which occurs naturally in the Cerrado and Atlantic Forest. The term 'mangaba' means 'good thing to eat' in Tupi-Guarani (SILVA JÚNIOR, 2004). In addition to fresh consumption, its fruits are widely used in the production of frozen pulp, sweets, ice cream and liqueurs.

The consumption of mangaba and its products are associated with the quality of antioxidant compounds, aromatic compounds and gastroprotective effect (MORAES et al., 2008; LIMA et al., 2015). Chemical characterization of secondary metabolites of plants enables the tracking of bioactive substances in germplasm, besides ensuring better quality of raw material used in phytotherapy programs and pharmaceutical industry (ALVES et al., 2010).

The Mangaba Active Germplasm Bank of Embrapa Coastal Tablelands, a registered depositary of the species (MMA/CGEN/ 02000.002581/201453), was implemented in 2006 and is composed of 27 accessions represented by 299 genotypes. The first fruiting occurred in 2013, and Silva et al. (2015) identified accessions whose fruits had high vitamin C content (226.63 and $244.43 \mathrm{mg} .100 \mathrm{~g}^{-1} \mathrm{FM}$ ) and evaluated the total polyphenols (from 88.81 to 148 $\mathrm{mg} .100 \mathrm{~g}^{-1}$ ) and antioxidant activity (between 3.91 and $12.20 \mu \mathrm{M}$ Trolox/g). In 2017, with a higher number of adult plants and in the fruiting stage, Santos et al. (2017) observed accessions with vitamin $\mathrm{C}$ content greater than $400 \mathrm{mg} / 100 \mathrm{~g}^{-1} \mathrm{FM}$ and suggested their use in future breeding programs of the species.

Results of the study conducted by Bastos et al. (2017) suggest that mangaba fruit is a source of valuable phenolic compounds. The chemical composition can be influenced by climate and genetic factors. The search for knowledge about the characterization of chemical composition together with genetic variability is extremely important to know the best genotypes with desired traits (COSTA et al., 2011), such as high vitamin $C$ content and that best adapt to the growing environment, for example.

Studies on antioxidant compounds and their use in the prevention or control of some diseases, such as arthritis, diabetes and cancer, have aroused the interest of the scientific community and general population. Among foods that contain natural antioxidants, fruits and vegetables are the ones that most contribute to the dietary supply of these compounds, associated with beneficial effects on human health (SUCUPIRA et al., 2012).

Growing epidemiological evidence of the role of antioxidant foods in disease prevention has led to the development of a large number of methods to determine antioxidant capacity (PÉREZ-JIMÉNEZ; SAURA-CALIXTO, 2006). The DPPH method (BRAND-WILLIAMS; CUVELIER; BERSET, 1995) is based on the scavenging of the DPPH radical (2,2-diphenyl-1-picrylhydrazyl) by antioxidants, producing a decrease in the absorbance of the DPPH free radical reaction with the antioxidant agent at $515 \mathrm{~nm}$ (RUFINO et al., 2007).

The objective of this study was to evaluate the bioactive compounds and antioxidant activity in fruits of mangaba accessions of the Active Germplasm Bank of Embrapa Coastal Tablelands.

\section{MATERIAL AND METHODS}

The fruits used came from six accessions in the production stage, from the Active Germplasm Bank of mangaba of Embrapa Coastal Tablelands (Table 1). The Active Germplasm Bank was implemented in 2006, in an non-irrigated area of restinga, in soil classified as Espodossolo Humilúvico (Spodosol), in the municipality of

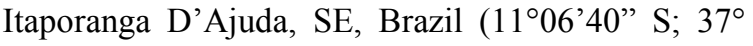
11 '15" W; altitude $9 \mathrm{~m}$ ).

Table 1. Origin (state and municipality), coding and number of plants of the accessions of the Active Germplasm Bank of mangaba of Embrapa Coastal Tablelands in fruiting stage.

\begin{tabular}{cccc}
\hline State & Municipality & Accessions/Coding & Number of plants \\
\hline \multirow{2}{*}{ Bahia } & Jandaíra & Costa Azul (CA) & 6 \\
& Conde & Barra de Itariri (BI) & 6 \\
& Mata de São João & Lagoa Grande (LG) & 6 \\
\hline \multirow{2}{*}{ Sergipe } & Indiaroba & Terra Caída (TC) & 6 \\
& & Preguiça (PR) & 6 \\
& & Pontal (PT) & 6 \\
\hline
\end{tabular}

Lyophilized mangaba pulps were extracted by ultrasound, using $5 \mathrm{~g}$ of pulp with $100 \mathrm{~mL}$ of methanol:water solvent $(9: 1, \mathrm{v} / \mathrm{v})$ in an ultrasonic washer (Unique Ultrasonic Cleaner USC-2800), with dimensions of $300 \times 240 \times 150 \mathrm{~mm}$, maximum power of $145 \mathrm{~W}$ and frequency of $40 \mathrm{KHz}$, for 30 minutes at $35^{\circ} \mathrm{C}$. The extractions were performed in triplicate and the temperature was monitored with a 
digital thermometer. The crude hydroalcoholic extract $(9: 1 \mathrm{v} / \mathrm{v}$, methanol/water $)$ obtained was subjected to simple filtration, concentrated in rotary evaporator and stored at $-20^{\circ} \mathrm{C}$.

Total phenols were determined in a UV-VIS spectrophotometer (1800 model, Shimadzu, Japan). The phenolic compounds of mangaba methanolic extracts were measured using the colorimetric method with Folin-Ciocalteu (SINGLETON; ROSSI, 1965). In a test tube, $50 \mu \mathrm{L}$ of extract were added with $3 \mathrm{~mL}$ of deionized water and $250 \mu \mathrm{L}$ of FolinCiocalteu $(1 \mathrm{~N})$. The solution was homogenized in vortex mixer, with subsequent rest for 8 minutes. Then, solution of $\mathrm{Na}_{2} \mathrm{CO}_{3}$ (sodium carbonate) $(20 \%$ $\mathrm{m} / \mathrm{v}$ ) and $950 \mu \mathrm{L}$ of deionized water were added. After 30 minutes in the dark, reading was performed at $765 \mathrm{~nm}$ on a spectrophotometer. The procedure for analysis of total phenols was performed in triplicate, in a light-free environment. Quantification was carried out by the external standardization method. The gallic acid standard was used as a reference for the calibration curve, and the concentration of phenolic compounds was expressed in milligrams of gallic acid equivalents (GAE). $100 \mathrm{~g}^{-1}$ of dry mass.

The determination of antioxidant activity through the DPPH radical followed the methodology of Rufino et al. (2007), based on the scavenging of the DPPH radical (2,2-diphenyl-1-picrylhydrazyl) by antioxidants. The DPPH radical solution $(60 \mu \mathrm{M})$ was prepared with $2.4 \mathrm{mg}$ of diluted DPPH, completed with methanol in $100-\mathrm{mL}$ volumetric flask, homogenized and transferred to amber vial. In test tubes, three different dilutions of the extracts obtained by ultrasound extraction (1:1, 1:5 and 1:10) were prepared. $3.9 \mathrm{~mL}$ of DPPH radical solution were added to the $0.1 \mathrm{~mL}$ volume of dilution and vortex mixed. After $30 \mathrm{~min}$, reading was performed at $515 \mathrm{~nm}$ in a UV-VIS spectrophotometer (1800 model, Shimadzu), using methyl alcohol as blank. Antioxidant activity was calculated from the standard DPPH curve in $\mu \mathrm{M}$ and the results were expressed in $\mathrm{g}_{\mathrm{g}} \mathrm{g}^{-1} \mathrm{DPPH}$.

Analysis of extracts of mangaba accessions was carried out using a high-performance liquid chromatograph (Agilent Technologies ${ }^{\circledR} \quad 1290$ Infinity). The analytes were separated in a C18 reverse phase column (Phenomenex, USA), with 150 $\mathrm{nm}$ in length, $4.6 \mathrm{~mm}$ internal diameter, $5 \mu \mathrm{m}$ particle size and C-18 guard column (Phenomenex, USA) with $20 \mathrm{~mm}$ length and $4.6 \mathrm{~mm}$ internal diameter, kept inside an oven with controlled temperature of $30{ }^{\circ} \mathrm{C}$. Wavelengths were 254,310 and $325 \mathrm{~nm}$ for rutin, ferulic acid and chlorogenic acid, respectively. The elution system in gradient mode with mobile phase was composed of acetic acid solution $(5 \%)$ in water (A) and methanol (B) (Table 2), mobile phase flow rate of 1,000 mL. $\mathrm{min}^{-1}$, injection volume of $20 \mu \mathrm{L}$ of the solution, and running time of $80 \mathrm{~min}$. The identified phenolic compounds were quantified by the external standardization method. The results were expressed in $\mathrm{mg} .100 \mathrm{~g}^{-1}$ of mangaba extract.

Table 2. Gradient elution program in HPLC-DAD developed for the analysis of phenolic compounds in mangaba.

\begin{tabular}{ccc}
\hline Time $(\min )$ & Acetic Acid $(5 \%)$ & Methanol (\%) \\
\hline 1 & 80 & 20 \\
10 & 80 & 20 \\
65 & 40 & 60 \\
70 & 20 & 80 \\
75 & 20 & 80 \\
78 & 80 & 20 \\
80 & 80 & 20 \\
\hline
\end{tabular}

Principal Component Analysis (PCA) and Hierarchical Cluster Analysis (HCA) were applied to the study of the similarity of individuals based on the distribution of chemical composition and antioxidant activity using R software, version 3.2.5.2016, with Princomp and factoextra packages.

The experimental design was completely randomized, with six treatments and six replicates. The data were subjected to analysis of variance by $\mathrm{F}$ test, and the means were compared by the Bonferroni test, at $5 \%$ probability level. Statistical analyses were carried out using the program SAS ${ }^{\circledR}$.

\section{RESULTS AND DISCUSSION}

Extraction yields - There was a significant difference in the yield of the different accessions of mangaba evaluated. The values ranged from 39.36 to 47.09 g. $100 \mathrm{~g}^{-1}$. Fruits of the accessions BI and LG, from the state of Bahia, had the highest averages (46.21 and 47.09 g. $100 \mathrm{~g}^{-1}$ ), respectively (Table 3). 
Table 3. Ultrasound extraction yield of the evaluated mangaba accessions.

\begin{tabular}{cc}
\hline Accession & Extract yield $\left(\mathrm{g} .100 \mathrm{~g}^{-1}\right)$ \\
\hline PR & $43.47 \pm 1.98 \mathrm{ab}$ \\
PT & $44.72 \pm 2.23 \mathrm{ab}$ \\
TC & $42.83 \pm 1.85 \mathrm{ab}$ \\
BI & $46.21 \pm 2.61 \mathrm{a}$ \\
CA & $39.36 \pm 2.03 \mathrm{~b}$ \\
LG & $47.09 \pm 2.06 \mathrm{a}$ \\
\hline CV (\%) & 4.87 \\
P & 0.01 \\
\hline
\end{tabular}

CV $(\%)=$ Coefficient of variation

*Means followed by the same letter in the same column, do not differ by Bonferroni test at $5 \%$ probability.

Total phenolic compounds content and antioxidant activity - Fruits of the accessions PR and CA showed higher content of total phenolics (1167.05 and $1179.39 \mathrm{mg} \mathrm{GAE} .100 \mathrm{~g}^{-1}$, respectively) than those of the other accessions (Table 4). The values found in the present study were higher than those reported by Lima et al. (2015) (490 mg GAE. $\left.100 \mathrm{~g}^{-1}\right)$, Rufino et al. (2010) $(169 \pm 21.5 \mathrm{mg}$ GAE. $\left.100 \mathrm{~g}^{-1}\right)$ and Almeida et al. (2011) (98.8 \pm 5.6 $\mathrm{mg}$ GAE. $\left.100 \mathrm{~g}^{-1}\right)$. For antioxidant activity, there was no significant difference between accessions. The values ranged from 125.95 to 158.67 g.g ${ }^{-1} \mathrm{DPPH}$
(Table 4), which are lower than those reported by Rufino et al. (2010) (890 g.g ${ }^{-1}$ DPPH) and Vidal (2010) $\left(5,792.66 \quad\right.$ g.g ${ }^{-1}$ DPPH). Despite the significant difference between the values of phenolic compounds, the DPPH free radical scavenging activity was not significant, possibly because the determination of antioxidant activity is related to the combined effect of these compounds in the sample. There was a synergistic effect of the antioxidant compounds in the sample that were not identified and quantified by HPLC.

Table 4. Total phenolic content and antioxidant activity in pulp extracts of mangaba accessions of the Active Germplasm Bank of Embrapa Coastal Tablelands.

\begin{tabular}{|c|c|c|}
\hline Accession & $\begin{array}{l}\text { Total phenolic content } \\
\left(\mathrm{mg} \text { GAE. } 100 \mathrm{~g}^{-1}\right)\end{array}$ & $\begin{array}{c}\text { Antioxidant activity } \\
\left.\text { (g.g } \text { g }^{-1} \mathrm{DPPH}\right)\end{array}$ \\
\hline PR & $1167.05 \pm 80.17 \mathrm{a}$ & $158.67 \pm 20.71 \mathrm{a}$ \\
\hline PT & $993.45 \pm 43.16 \mathrm{ab}$ & $156.02 \pm 7.80 \mathrm{a}$ \\
\hline $\mathrm{TC}$ & $955.96 \pm 79.48 b$ & $150.54 \pm 0.95 \mathrm{a}$ \\
\hline $\mathrm{BI}$ & $899.68 \pm 90.86 b$ & $125.95 \pm 11.70 \mathrm{a}$ \\
\hline $\mathrm{CA}$ & $1179.39 \pm 46.34 \mathrm{a}$ & $153.00 \pm 20.04 \mathrm{a}$ \\
\hline LG & $903.15 \pm 38.93 b$ & $143.51 \pm 1.96 \mathrm{a}$ \\
\hline CV (\%) & 6.54 & 9.60 \\
\hline P & 0.0004 & 0.34 \\
\hline
\end{tabular}

$\mathrm{CV}(\%)=$ Coefficient of variation

*Means followed by the same letter in the same column, do not differ by Bonferroni test at $5 \%$ probability.

Identification and quantification of bioactive compounds by HPLC - Three phenolic compounds were identified and quantified by highperformance liquid chromatography (HPLC), one flavonoid (rutin) and two phenolic acids (ferulic acid and chlorogenic acid). Rutin was the compound with highest concentration and ferulic acid was the one with lowest concentration (Table 5). The presence of rutin and chlorogenic acid has also been reported by Lima et al. (2015) and Rufino et al. (2010). 
Table 5. Concentrations of chlorogenic acid, ferulic acid and rutin obtained in pulp extracts of mangaba accessions of the Active Germplasm Bank of Embrapa Coastal Tablelands.

\begin{tabular}{cccc}
\hline Accession & $\begin{array}{c}\text { Chlorogenic acid } \\
\left(\mathrm{mg}_{\left.100 \mathrm{~g}^{-1}\right)}\right.\end{array}$ & $\begin{array}{c}\text { Ferulic acid } \\
\left(\mathrm{mg} .100 \mathrm{~g}^{-1}\right)\end{array}$ & Rutin $\left(\mathrm{mg} .100 \mathrm{~g}^{-1}\right)$ \\
\hline PR & $93.71 \pm 14.51 \mathrm{~b}$ & $0.93 \pm 0.29 \mathrm{~b}$ & $236.90 \pm 20.39 \mathrm{c}$ \\
PT & $96.83 \pm 4.03 \mathrm{~b}$ & $0.90 \pm 0.29 \mathrm{~b}$ & $234.56 \pm 16.36 \mathrm{c}$ \\
TC & $112.98 \pm 14.88 \mathrm{ab}$ & $2.27 \pm 0.13 \mathrm{a}$ & $436.78 \pm 3.09 \mathrm{a}$ \\
BI & $116.14 \pm 8.58 \mathrm{ab}$ & $1.23 \pm 0.07 \mathrm{~b}$ & $238.59 \pm 12.01 \mathrm{c}$ \\
CA & $131.66 \pm 14.18 \mathrm{a}$ & $0.85 \pm 0.03 \mathrm{~b}$ & $442.94 \pm 19.60 \mathrm{a}$ \\
LG & $115.03 \pm 8.46 \mathrm{ab}$ & $1.22 \pm 0.03 \mathrm{~b}$ & $319.39 \pm 14.23 \mathrm{~b}$ \\
\hline CV $(\%)$ & 10.05 & 14.75 & 4.48 \\
P & 0.02 & 0.0001 & 0.0001 \\
\hline
\end{tabular}

$\mathrm{CV}(\%)=$ Coefficient of variation

*Means followed by the same letter in the same column, do not differ by Bonferroni test at $5 \%$ probability.

There was a significant difference between the mangaba accessions for the concentrations of chlorogenic acid, ferulic acid and rutin (Table 5) and these values were correlated with the origin of the individuals.

Chlorogenic acid is a secondary metabolite synthesized by phenylpropanoid pathway of phenylalanine via cinnamic acid. It is the ester of caffeic and L-quinic acids (3-caffeoylquinic acid). Its biological activities include antioxidant properties (SATO et al., 2011), antimicrobial effects (PUUPPONEN-PIMIA et al., 2001) and antiviral activity (WANG et al., 2009). For this bioactive compound, the accession $\mathrm{CA}$ had the highest concentration (131.66 mg. $\left.100 \mathrm{~g}^{-1}\right)$. The accessions PR (93.71 mg.100g $\mathrm{g}^{-1}$ ) and PT (96.83 mg.100 $\mathrm{g}^{-1}$ ) obtained the lowest averages and did not differ statistically from TC (112.98 mg. $\left.100 \mathrm{~g}^{-1}\right)$, BI (116.14 mg. $\left.100 \mathrm{~g}^{-1}\right)$ and LG (115.03 mg. $\left.100 \mathrm{~g}^{-1}\right)$.

The study of chlorogenic acid concentration in different genotypes of guelder-rose (Viburnum opulus) was reported by Kraujalytė et al. (2013), who found different values of chlorogenic acid content ( 0.54 to $6.93 \mathrm{mg} / \mathrm{mL})$ among genotypes of the same cultivar. In mangaba, Gomes et al. (2013) observed chlorogenic acid concentrations of $11.34 \mathrm{mg} .100 \mathrm{~g}^{-1}$ and Lima et al. (2015) found values of $18.091 \pm 1.68 \mathrm{mg} .100 \mathrm{~g}^{-1}$.

For ferulic acid, which can be used in the treatment of Alzheimer's disease, cancer, cardiovascular diseases, diabetes mellitus and skin diseases (MANCUSO; SANTANGELO, 2014), the highest concentration was observed in the accession TC (2.27 mg. $\left.100 \mathrm{~g}^{-1}\right)$.

For rutin, the accessions TC and CA obtained the highest averages (436.78 and $442.94 \mathrm{mg} .100 \mathrm{~g}^{-1}$, respectively). The mean value found in the present study for rutin was $318.19 \mathrm{mg} .100 \mathrm{~g}^{-1}$, much higher than that reported by Lima et al. (2015), 10.260土 $1.13 \mathrm{mg} .100 \mathrm{~g}^{-1}$. The accessions TC and CA had the highest concentrations of rutin and can be selected for future breeding programs, showing that genetic factors can modulate the composition and concentration of phytochemicals. Rutin is a flavonoid with antioxidant, anti-inflammatory and anticancer activities and great therapeutic importance for improving the resistance and permeability of capillary vessels (BECHO; MACHADO; OLIVEIRA, 2009).

Although all fruits were harvested at the same time and at the same maturity stage, there was a variation in the contents of phenolic compounds, which can be explained by the genetic variability existing among the accessions studied, already reported by Costa et al. (2011).

In addition to the compounds observed in this study, Lima et al. (2015) worked with fresh mangaba pulp and identified by HPLC-DAD gallic acid, catechin, vanillic acid, p-coumaric acid and rosmarinic acid, with predominance of chlorogenic acid (18.09 mg.100-1 $)$ and rutin (11.34 mg.100 $\left.{ }^{-1}\right)$.

Principal component analysis (PCA) - This analysis enabled a multivariate study of the experimental data, facilitating the visualization of the correlation between the six mangaba accessions and the variables - total phenols, antioxidant activity, and concentrations of ferulic acid, chlorogenic acid and rutin. The accessions were grouped into four groups: Group 1 (G1), formed by CA; Group 2 (G2), formed by TC; Group $3(\mathrm{G} 3)$, formed by PR and PT, and group 4 (G4), formed by BI and LG (Figure 1). 


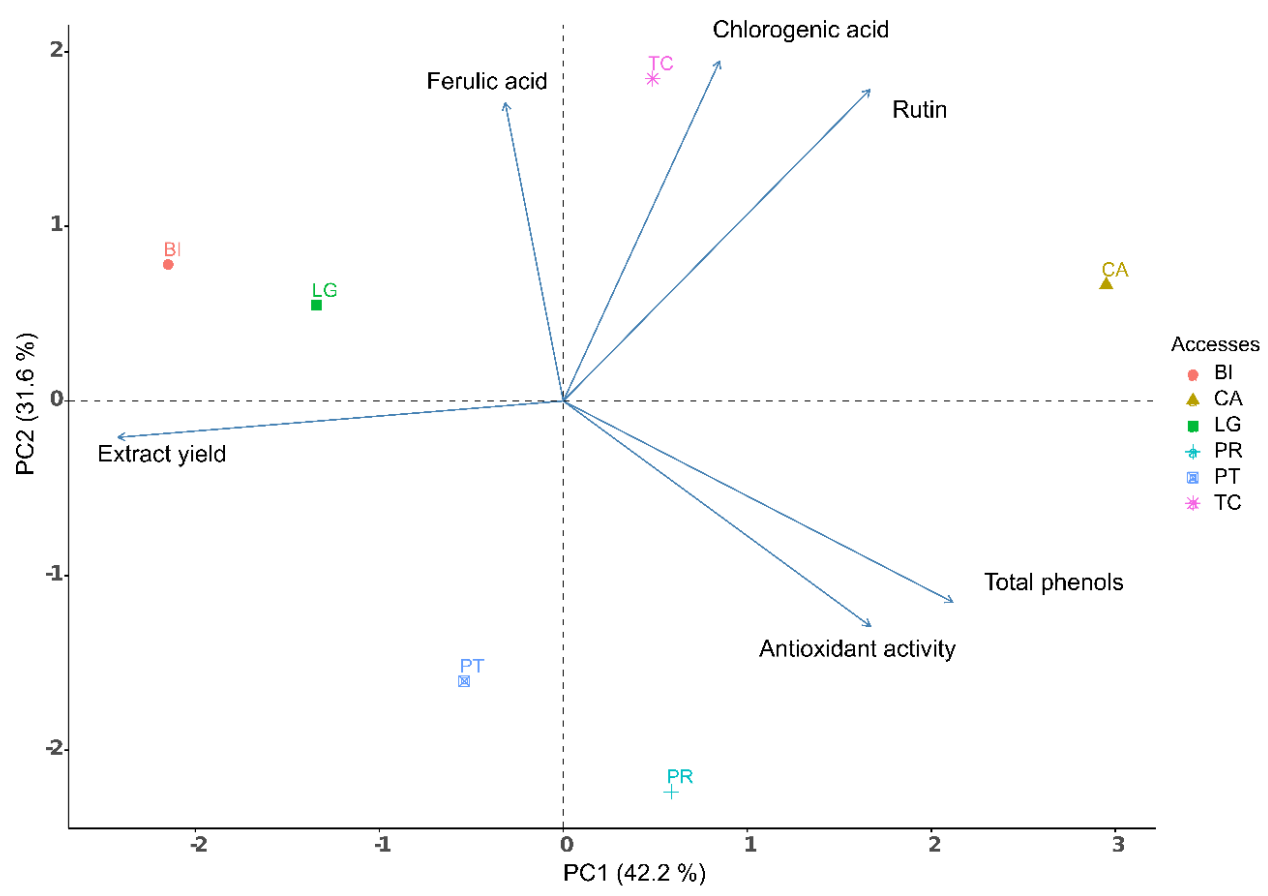

Figure 1. Principal Component Analysis (PCA) of the six mangaba accessions (BI, CA, LG, PR, PT and TC) of the Active Germplasm Bank evaluated in relation to total phenols, antioxidant activity and concentrations of ferulic acid, chlorogenic acid and rutin.

The first two principal components represented approximately $74 \%$ of the total variation of the information contained in the mean values of the five variables analyzed (total phenols, antioxidant activity and concentrations of ferulic acid, chlorogenic acid and rutin). The first principal component (PC1) represented $42.2 \%$ of all information for the six accessions (PR, PT, TC, BI, $\mathrm{CA}$ and $\mathrm{LG}$ ). In this component, Group 3 (PR and PT accessions) was characterized by having the highest value of total phenol content. The second principal component (PC2) corresponded to $31.6 \%$ of the variation, in which Group 2 (TC accession) stood out with the highest positive weights for the ferulic acid concentration variable. The accessions CA and TC were clearly separated by the highest and lowest ferulic acid contents, respectively (Figure 1).

For the chemical composition based on the content of total phenols, ferulic acid, chlorogenic acid, rutin and antioxidant activity, the accessions were classified into four distinct groups by hierarchical cluster analysis (HCA): Group 1 (G1), composed of the accession $\mathrm{CA}$ and characterized by having the highest concentrations of chlorogenic acid and rutin; Group 2 (G2), formed by the accession TC, with the highest concentration of ferulic acid; Group 3 (G3), formed by PR and PT, which had the highest antioxidant activity by the DPPH method, and Group 4 (G4), with the accessions BI and LG, characterized by having similar values of chlorogenic acid and ferulic acid (Figure 2).

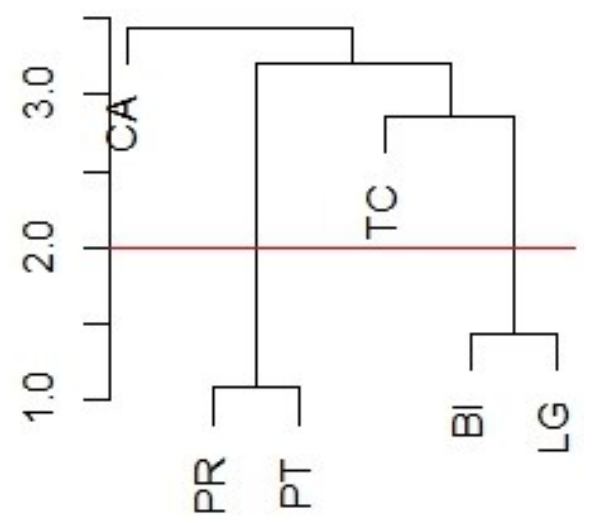

Figure 2. Hierarchical Cluster Analysis (HCA) of the six mangaba accessions (BI, CA, LG, PR, PT and TC) of the Active Germplasm Bank studied in relation to chemical composition and antioxidant activity. 
The CA accession was the furthest from the others, indicating that it has well-defined chemical characteristics and genetic traits. In this analysis, Group 2 with the accession TC, separated from the others by the PCA, was close to Group 4, containing the accessions BI and LG, and the two multivariate analyses show the same grouping.

\section{CONCLUSIONS}

This was the first report on the quantification and identification of bioactive compounds in fruits of the accessions of the Active Germplasm Bank of Embrapa Coastal Tablelands, showing correlation between the total phenol content, antioxidant activity and quantity of phenolic compounds.

The antioxidant activity through the DPPH radical was lower than those reported in the literature and did not vary among accessions.

The accessions CA (from Bahia) and TC (from Sergipe) have higher concentration of the major compound rutin and can be indicated for selection in future mangaba breeding programs.

The extracts of the accessions CA and TC are the best ones for future pharmacological applications because they have the highest contents of the major compound rutin, and also of chlorogenic acid and ferulic acid.

\section{ACKNOWLEDGMENTS}

CNPq (process 301472/2018-1) and Embrapa Tabuleiros Costeiros.

\section{REFERENCES}

ALMEIDA, M. M. B. et al. Bioactive compounds and antioxidant activity of fresh exotic fruits from northeastern Brazil. Food Research International, 44: 2155-2159, 2011.

ALVES, R. D. B. et al. Manual de curadores de germoplasma-vegetal: caracterização química de metabólitos secundários em germoplasma vegetal. Brasília: Embrapa Recursos Genéticos e Biotecnologia, 2010. 12 p.

BASTOS, K. X. et al. Identification of phenolic compounds from Hancornia speciosa (Apocynaceae) leaves by uhplc orbitrap-hrms. Molecules, 22: 143, 2017.

BECHO, J. R. M.; MACHADO, H.; OLIVEIRA, M. G. Rutina-estrutura, metabolismo e potencial farmacológico. Revista Interdisciplinar de Estudos Experimentais, 1: 21-25, 2009.
BRAND-WILLIAMS，W.; CUVELIER， M. E.; BERSET, C. L. W. T. Use of a free radical method to evaluate antioxidant activity. LWT-Food science and Technology, 28: 25-30, 1995.

COSTA, T. S. et al. Genetic diversity of accessions of the mangaba germplasm bank in Sergipe, Brazil. Pesquisa Agropecuária Brasileira, 46: 499-508, 2011.

GOMES, E. B. et al. A rapid method for determination of some phenolic acids in brazilian tropical fruits of mangaba (Hancornia speciosa Gomes) and Umbu (Spondias tuberosa Arruda Camara) by UPLC. Journal of Analytical Sciences, Methods and Instrumentation, 3: 1-10, 2013.

KRAUJALYTÉ, V. et al. Antioxidant properties and polyphenolic compositions of fruits from different European cranberrybush (Viburnum opulus L.) genotypes. Food Chemistry, 141: 3695-3702, 2013.

LIMA, J. P. et al. First evaluation of the antimutagenic effect of mangaba fruit in vivo and its phenolic profile identification. Food Research International, 75: 216-224, 2015.

MANCUSO, C.; SANTANGELO, R. Ferulic acid: Pharmacological and toxicological aspects. Food and Chemical Toxicology, 65: 185-195, 2014.

MORAES, T. M. et al. Hancornia speciosa: indications of gastroprotective, healing and antiHelicobacter pylori actions. Journal of Ethnopharmacology, 120: 161-168, 2008.

PÉREZ-JIMÉNEZ, J.; SAURA-CALIXTO, F. Effect of solvent and certain food constituents on different antioxidant capacity assays. Food Research International, 39: 791-800, 2006.

PUUPPONEN-PIMIA, R. et al. Antimicrobial properties of phenolic compounds from berries. Journal of Applied Microbiology, 90: 494-507, 2001

RUFINO, M. S. M. et al. Metodologia científica: determinação da atividade antioxidante total em 46 frutas pela captura do radical livre DPPH. Fortaleza, CE: Embrapa Agroindústria Tropical, 2007. 4 p. (Comunicado Técnico, 127).

RUFINO, M. S. M. et al. Bioactive compounds and antioxidant capacities of 18 non-traditional tropical fruits from Brazil. Food Chemistry, 121: 996-1002, 2010 .

SANTOS, P. S. et al. Genetic diversity and the quality of mangabeira tree fruits (Hancornia speciosa Gomes-Apocynaceae), a native species 
from Brazil. Scientia Horticulturae, 226: 372-378, 2017.

SATO, Y. et al. In vitro and in vivo antioxidant properties of chlorogenic acid and caffeic acid. International Journal of Pharmaceutics, 403: 136 $-138,2011$.

SILVA, A. V. C. et al. Atributos de qualidade de funcionais de acessos do banco ativo de germoplasma de mangaba da Embrapa Tabuleiros Costeiros. Aracaju, SE: Embrapa Tabuleiros, 2015. 7 p. (Circular Técnica, 71).

SILVA JÚNIOR, J. F. A cultura da Mangaba. Revista Brasileira de Fruticultura, 26: 1-192, 2004.

SINGLETON, V. L.; ROSSI, J. A. Colorimetry of total phenolics with phosphomolybdic phosphotungstic acid reagents. American Journal of Enology and Viticulture, 16: 144-158, 1965.

SUCUPIRA, N. R. et al. Métodos para determinação da atividade antioxidante de frutos. UNOPAR Científica Ciências Biológicas e da Saúde, 14: 263269, 2012.

VIDAL, R. F. Caracterização, compostos bioativos e atividade antioxidante de genótipos de $\mathbf{7 4}$ mangabeiras (Hancornia speciosa Gomes) nativos do litoral cearense. 2010. 92 f. Dissertação (Mestrado em Fitotecnia: Área de Concentração em pós-colheita) - Universidade Federal do Ceará, Fortaleza, 2010.

WANG, G. F. et al. Antihepatitis B virus activity of chlorogenic acid, quinic acid and caffeic acid in vivo and in vitro. Antiviral Research, 83: 186-190, 2009. 